\title{
Plant Regeneration through Somatic Embryogenesis of Yacón [Smallanthus sonchifolius (Poepp. and Endl.) H. Robinson]
}

\author{
Cynthia Manyra Corrêa ${ }^{1}$, Graciele Nicolodi de Oliveira ${ }^{2}$, Leandro Vieira Astarita ${ }^{1}$ and $^{2}$ \\ Eliane Romanato Santarém ${ }^{\text {* }}$ \\ ${ }^{1}$ Laboratório de Biotecnologia Vegetal; Departamento de Biologia Celular e Molecular; Faculdade de Biociências; \\ Pontifícia Universidade Católica do Rio Grande do Sul; Av. Ipiranga, 6681; 90619-900; Porto Alegre - RS - Brasil. \\ ${ }^{2}$ Laboratório de Cultura de Tecidos Vegetais; Universidade de Cruz Alta; Cruz Alta - RS - Brasil
}

\begin{abstract}
Smallanthus sonchifolius has tuberous roots containing large amounts of fructo-oligosaccharides and its medicinal use has increased due to the hypoglycemic properties reported for this species. An efficient system for propagation via somatic embryogenesis is reported using petiole segments cultivated on MS medium supplemented with combinations of BA, kinetin and 2,4-D, under light and darkness conditions. Embryogenic callus was formed in most of the treatments; however, somatic embryogenesis was promoted by the presence of light. Clusters of somatic embryos appeared on callus surface after 50 days of culture. The highest number of embryos was produced on 0.45 $\mu M B A$ and $4.5 \mu M$ 2,4-D. Embryogenic calli were maintained on MS medium containing $4.5 \mu M$ BA and $0.045 \mu M$ 2,4-D. Embryos converted on hormone-free half-strength MS medium with 2 g. $L^{-1}$ activated charcoal and plantlets were transferred to non-sterile conditions for acclimatization, showing $100 \%$ of survival.
\end{abstract}

Key words: Medicinal plant, tissue culture, Polymnia sonchifolia, micropropagation

\section{INTRODUCTION}

Yacón [Smallanthus sonchifolius (Poepp. and Endl.) H. Robinson], a member of Asteraceae originally cultivated in the mountain regions of South America, has recently been introduced for cultivation in Brazil. It is a perennial herb, 2 to 2.5 $\mathrm{m}$ tall with a root system composed of 4 to 20 edible fleshy tuberous storage roots (Zardini, 1991). This species has received attention because of the high content of fructo-oligosaccharides in its roots. Considered by early Andean inhabitants as a "fruit", it has a relatively low energy value despite its juiciness and sweet taste (Aybar et al., 2001). Medicinally, yacón has been used as an auxiliary in the treatment of diabetes and digestive disorders. Aybar et al. (2001) demonstrated the hypoglycemic effect of the aqueous extract of yacón leaves in diabetic rats, suggesting that the extracts produce an increase in the concentration of plasma insulin. Recently, analysis of the leaf and tuber extracts showed that both parts of the yacón plant represented a rich source of phenolic acids and other radical scavenging compounds, suggesting antioxidant proprieties (Valentova et al., 2005).

*Author for correspondence: eliane.santarem@pq.cnpq.br 
Yacón is propagated from offset, stem cutting and tuber division. However, virus infections are frequent as result of asexual propagation (Grau and Rea, 1997). As alternative for multiplication and maintenance of germplasm of this species, efficient in vitro techniques have become necessary. Direct organogenesis from stem cuttings and leaf segments has been reported as a tool for germoplasm conservation (Estrella and Lazart, 1994; Niwa, 2002). In spite of the procedures described for organogenesis, somatic embryogenesis has not been reported for this species. In this work, somatic embryogenesis in yacón from vegetative parts of the plant was studied.

\section{MATERIAL AND METHODS}

\section{Somatic embryo induction}

Mature leaves of yacón [Smallanthus sonchifolius (Poepp. and Endl.) H. Robinson] were collected from one-year-old plants and surface disinfected by immersion in $20 \%(\mathrm{v} / \mathrm{v})$ commercial sodium hypoclorite solution $(0.4 \% \mathrm{NaClO})$ for $10 \mathrm{~min}$. Under aseptic conditions, leaves were rinsed in sterile distilled water and petiole segments $(5 \mathrm{~mm})$ were excised. The basal culture medium contained MS salts and vitamins (Murashige and Skoog, 1962), 30 g.L $\mathrm{L}^{-1}$ sucrose and 6 g.L $\mathrm{L}^{-1}$ agar. The $\mathrm{pH}$ was adjusted to 5.8 before autoclaving. The effect of different growth regulators on embryogenesis induction was tested by adding benzyladenine (BA) and kinetin (Kin) at 0.045 , 0.45 and $4.5 \mu \mathrm{M}$ to the basal medium in combination with 0.45 or $4.5 \mu \mathrm{M}$ of $2,4-$ dichlorophenoxyacetic acid (2,4-D). Hormonefree medium was used as control. Subcultures into fresh medium were carried out every 25 days. Cultures were maintained at $26 \pm 2{ }^{\circ} \mathrm{C}$ under light ( $16 \mathrm{~h}$ photoperiod at $30 \mu \mathrm{mol} \mathrm{m}{ }^{-2} \mathrm{~s}^{-1}$ of irradiance) or darkness. Somatic embryo proliferation was tested under light condition on medium supplemented with $4.5 \mu \mathrm{M} \mathrm{BA}$ and either 0.045 or $0.45 \mu \mathrm{M}$ 2,4-D.

Twenty explants were used per treatment. The experiment was repeated twice. The embryogenic efficiency was calculated as the number of embryogenic callus per total number of explants after 50 days of culture initiation. Callus was considered embryogenic when presented at least one somatic embryo. The number of somatic embryos induced per explant was also evaluated at 50 days. Data were normalized using transformation $x^{\prime}=\log (x+1)$ (Fowler and Cohen, $1990)$ and analyzed by analysis of variance. Means were separated using the Tukey's test, $\alpha=0.05$.

\section{Embryo conversion}

Somatic embryos induced on callus were separated and transferred to half-strength MS medium ( $1 / 2$ MS) containing 20 g. $\mathrm{L}^{-1}$ sucrose, $2 \mathrm{~g} . \mathrm{L}^{-1}$ activated charcoal and 6 g. $\mathrm{L}^{-1}$ agar and cultivated under light conditions. Regenerated plants were recorded after 30 days. In vitro plantlets with well-developed roots were removed from the culture medium and roots were gently washed under running tap water. Plantlets were transferred to plastic bags containing a moistened mixture of soil and vermiculite (2:1) under non-sterile conditions. Potted plants were covered with a clear plastic bag and maintained inside the plant growth chamber at $26 \pm 2{ }^{\circ} \mathrm{C}$ and $16 \mathrm{~h}$ photoperiod for 7 days. Plants were acclimated to ambient humidity levels by gradually removing the plastic bag during the following 5 days. Acclimated plants were then transferred to a greenhouse and the number of surviving plants was recorded after 10 days.

\section{Histological analysis}

For histological studies, the embryogenic and non embryogenic calli were collected during the induction process. Samples were fixed in glutaraldehyde, dehydrated through an ethanol series, infiltrated with Historesin Plus (Leica) and further sectioned ( $5 \mu \mathrm{m}$ thickness) using a rotatory microtome (Leica). The sections were stained with $0.05 \%$ toluidine blue and observed under light microscope (Zeiss).

\section{RESULTS AND DISCUSSION}

Cultivation of petiole segments from yacón leaves on media supplemented with various combinations of BA, Kin and 2,4-D resulted on induction of embryogenic calli in most of the treatments tested, regardless the presence or absence of light during the induction phase. Most treatments resulted in high frequencies of embryogenic callus formation $(>70 \%)$, with the exception of the media in which $0.45 \mu \mathrm{M}$ 2,4-D was added along with higher concentrations of BA or Kin $(4.5 \mu \mathrm{M})$ (Table 1). Embryogenic calli were not formed when explants 
were cultured either on medium devoid of any growth regulator or in the presence of BA or Kin individually, although proliferation of undifferentiated cell masses was obtained (Table 1). Callus proliferation from tissues of most dicotyledonous plants usually requires the presence of both an auxin and a cytokinin in the growth medium. The addition of cytokinin ( 0.1 to $1 \mu \mathrm{M}$ BA or Kin) to the medium tends to increase the growth rate of embryogenic callus (George,
1993). Nevertheless, although there was a beneficial effect resulting from the combination of auxin and cytokinin, the presence of 2,4-D alone also promoted the embryogenic callus formation (Table 1).

Clusters of somatic embryos were recorded on the callus surface after 50 days of culture (Fig.1A).Induction of somatic embryos was affected by culture medium composition and light conditions.

Table 1 - Effect of different types and concentrations of growth regulators on induction of embryogenic callus and somatic embryos of yacón (Smallanthus sonchifolius) in the presence or absence of light.

\begin{tabular}{|c|c|c|c|c|c|c|c|c|}
\hline \multirow{2}{*}{$\begin{array}{l}\text { Treatments } \\
\text { Growth regulators }(\mu \mathrm{M}) \\
\end{array}$} & \multicolumn{2}{|c|}{ Embryogenic callus induction $(\%)^{a}$} & \multicolumn{6}{|c|}{ Somatic embryos per embryogenic callus } \\
\hline & Light & Darkness & & Light & & & rknes & \\
\hline 0.0 (control) & 0 & 0 & - & & & - & & \\
\hline $4.5 \mathrm{BA}$ & 0 & 0 & - & & & - & & \\
\hline $4.5 \mathrm{KIN}$ & 0 & 0 & - & & & - & & \\
\hline $4.52,4-\mathrm{D}$ & 100 & 100 & 22.0 & $\mathrm{ab}$ & A & 8.6 & $\mathrm{ab}$ & $\mathrm{B}$ \\
\hline $0.045 \mathrm{BA}+4.52,4-\mathrm{D}$ & 100 & 100 & 24.0 & $a b$ & A & 7.4 & $\mathrm{ab}$ & A \\
\hline $0.45 \mathrm{BA}+4.52,4-\mathrm{D}$ & 100 & 90 & 28.4 & a & A & 6.6 & $\mathrm{ab}$ & $\mathrm{B}$ \\
\hline $4.5 \mathrm{BA}+4.52,4-\mathrm{D}$ & 87.5 & 70 & 9.7 & $\mathrm{bc}$ & A & 5.7 & $\mathrm{ab}$ & A \\
\hline $0.045 \mathrm{KIN}+4.52,4-\mathrm{D}$ & 100 & 100 & 22.8 & $\mathrm{ab}$ & A & 7.3 & $\mathrm{ab}$ & B \\
\hline $0.45 \mathrm{KIN}+4.52,4-\mathrm{D}$ & 100 & 100 & 23.3 & $\mathrm{ab}$ & A & 9.8 & $\mathrm{a}$ & B \\
\hline $4.5 \mathrm{KIN}+4.52,4-\mathrm{D}$ & 100 & 70 & 14.0 & $a b c$ & A & 4.7 & $\mathrm{~b}$ & $\mathrm{~B}$ \\
\hline $4.5 \mathrm{BA}+0.452,4-\mathrm{D}$ & 10 & 0 & 1.1 & $\mathrm{~d}$ & A & - & & \\
\hline $4.5 \mathrm{KIN}+0.452,4-\mathrm{D}$ & 60 & 40 & 2.3 & $\mathrm{~cd}$ & A & 1.2 & $\mathrm{~b}$ & A \\
\hline
\end{tabular}

${ }^{a}$ Frequency of embryogenic callus induction and average number of somatic embryos per embryogenic callus from two independent experiments after 50 days of cultivation.

Means followed by different small letters in each column and capital letters in each row are significantly different according to Tukey's Test at $P \leq 0.05$.

The presence of light promoted somatic embryogenesis on callus induced under various combinations of growth regulators, reaching an average of 28.4 embryos per callus, while under darkness only 9.8 somatic embryos were observed (Table 1). Requirement of light during in vitro morphogenetic processes has been proved to depend on the species tested. Somatic embryos were induced when explants were cultured either in the presence of light (Fernando et al., 2002; Martin et al., 2000; Martin, 2003) or under dark conditions (Fernando et al., 2001; Gogate et al., 2003). Medium composition affected the embryogenic response of yacón as well. The highest number of embryos was observed on callus induced on medium supplemented with low BA and Kin along with $4.5 \mu \mathrm{M}$ 2,4-D under light. In Anacardium occidentale, BA was the most effective growth regulator for somatic embryogenesis (Martin, 2003), while Kin combined with NAA or 2,4-D was found optimal for embryogenesis in cultures of Valeriana edulis and Azadirachta excelsa (Castillo et al., 2000; TeChato and Rungnoi, 2000). Although the addition of 2,4-D as the only growth regulator resulted in efficient embryo induction (an average of 22 embryos per embryogenic callus), all embryos failed to germinate. Thereby, a combination of cytokinin and auxin appeared to be essential for embryogenesis in yacón and the presence of light seemed to enhance this morphogenetic process. Histological examinations by serial sections 
revealed that embryogenic calli were more friable and yellowish in appearance than the non embryogenic calli. Regions with densely staining cells were observed at the peripheral layer of friable callus (Fig. 1B). Somatic embryos were observed to arise from the outermost cell layer of the callus and no vascular connection between the callus and the developing embryos was observed (Fig. 1C). Similarly, somatic embryos of Carica papaya L. were originated from embryogenic superficial cells located on peripheral cell layers of callus (Fernando et al., 2001). Somatic embryos induced on different treatments were transferred to proliferation medium with $4.5 \mu \mathrm{M} \mathrm{BA}$ and 0.045 or $0.45 \mu \mathrm{M} 2,4-\mathrm{D}$. Though the media evaluated did not result on embryo proliferation, the addition of $0.045 \mu \mathrm{M}$ 2,4-D led somatic embryos to develop through globular to cotyledonary stage within 30 days (Fig. 1D). Since no embryo germination into complete plants was obtained on this medium, developed embryos were transferred to hormone-free conversion medium, containing activated charcoal. Embryo conversion or germination was defined as the development of embryos into plantlets with well-defined root and shoot systems.
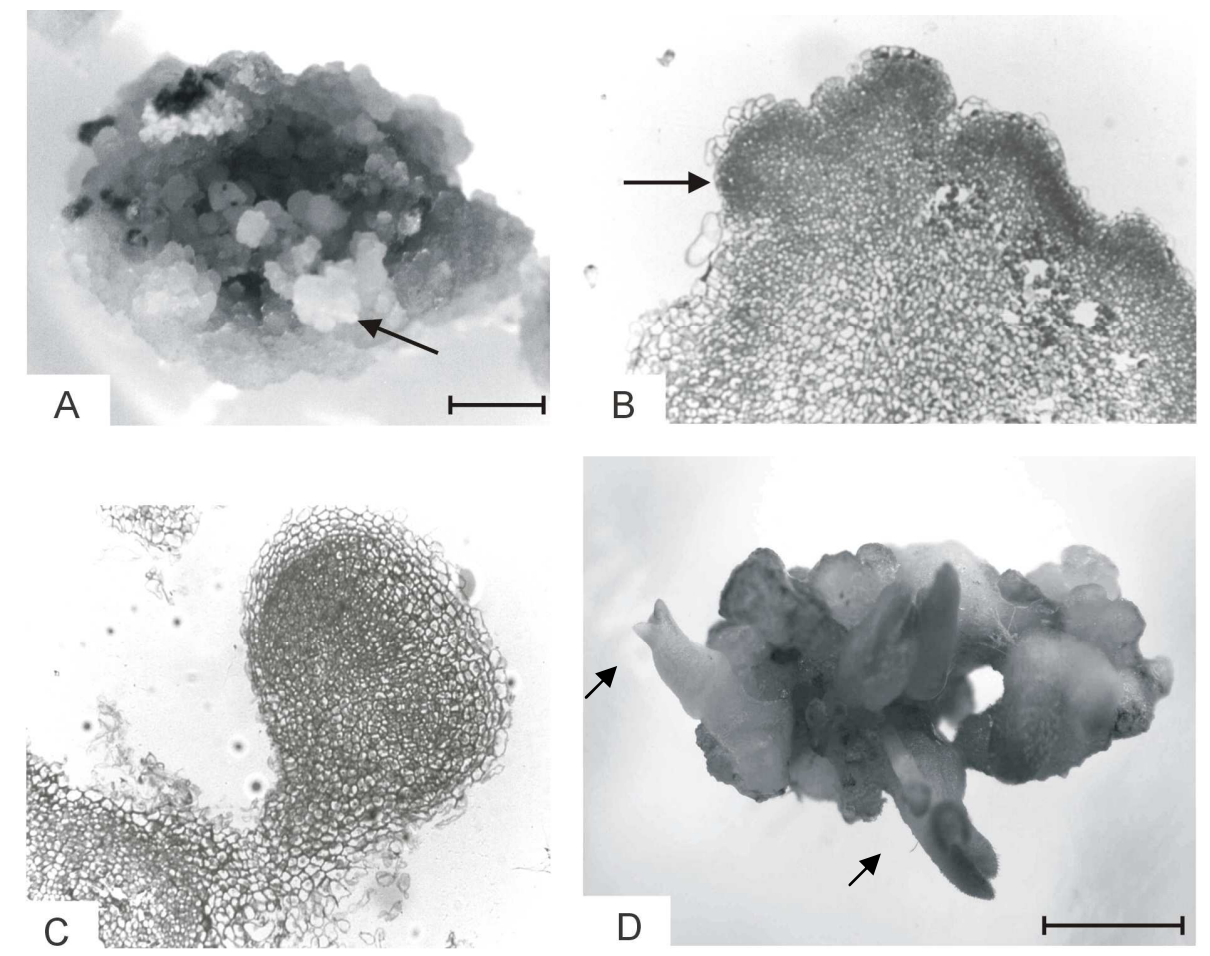

Figure 1 - Somatic embryogenesis and plant regeneration in yacón (Smallanthus sonchifolius). (A) Embryogenic callus induced on $0.45 \mu \mathrm{M}$ BA $+4.5 \mu \mathrm{M} 2,4-\mathrm{D}$ after 50 days of culture. Arrow indicates a cluster of somatic embryos. Bar represents $2 \mathrm{~mm}$. (B) Longitudinal section of embryogenic callus showing densely stained cells at peripheral layer (arrow) (100x). (C) Longitudinal section of a somatic embryo (400x) (D) Developed somatic embryo (arrows). Bar represents $3 \mathrm{~mm}$.

Embryos that were induced in the presence of either BA or Kin $(0.045 \mu \mathrm{M}$ and $0.45 \mu \mathrm{M})$ and 4.5 $\mu \mathrm{M}$ 2,4-D were able to convert into plantlets (Fig. 2A). However, the highest percentage of conversion (52\%) was obtained from embryos induced on $0.45 \mu \mathrm{M}$ BA and $4.5 \mu \mathrm{M} 2,4-\mathrm{D}$ and cultivated on hormone-free $1 / 2$ MS conversion medium (Fig. 2A). Conversion of somatic embryos in plantlets on medium MS without growth regulators have also been reported for several medicinal species (Rout et al., 2000; TeChato and Rungnoi, 2000; Gogate et al., 2003). In vitro plantlets of yacón with well-developed roots were transferred to non-sterile conditions and acclimated to ambient humidity (Fig. 2B). All transferred plants survived. 

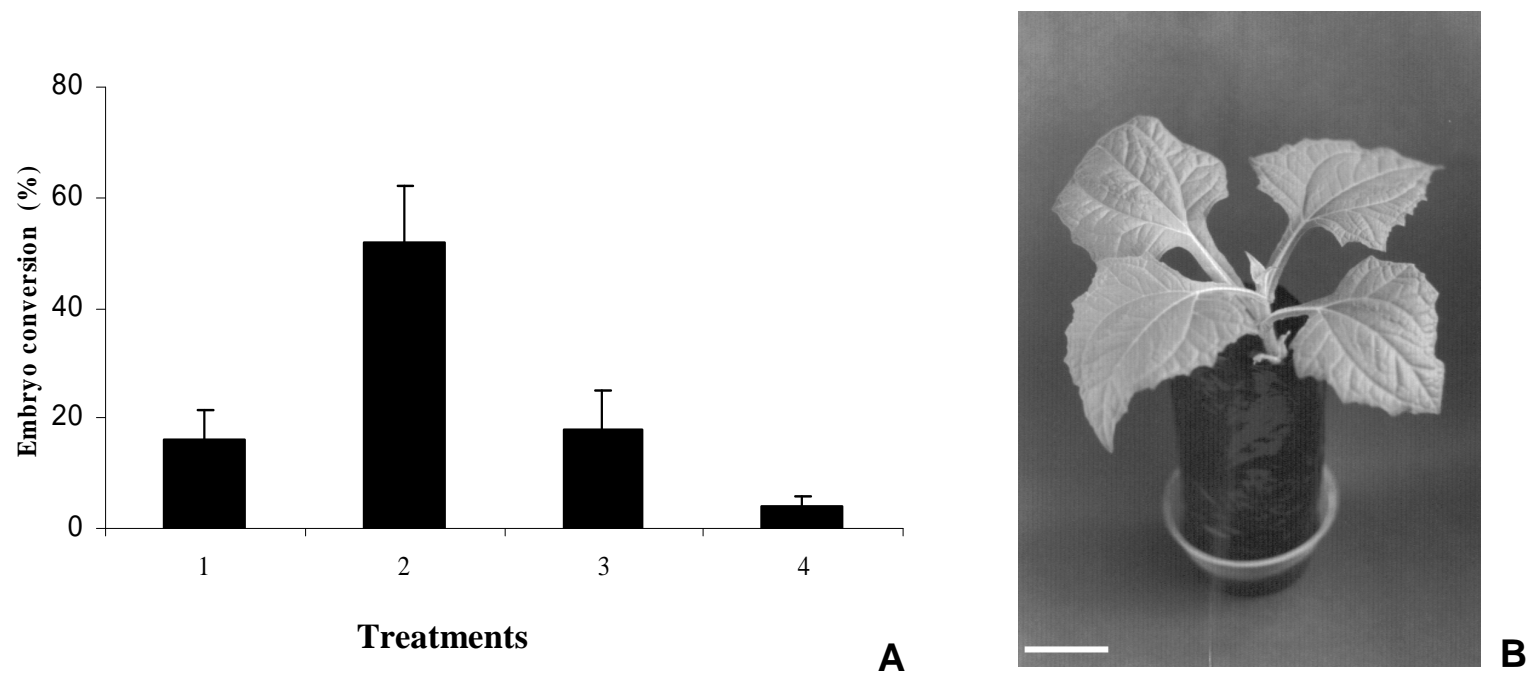

Figure 2 - (A) Conversion of somatic embryos of yacón (Smallanthus sonchifolius) on hormone-free MS medium supplemented with $2 \mathrm{~g} . \mathrm{L}^{-1}$ activated charcoal. Treatments refer to the culture media used for somatic embryos induction, under light conditions: (1) $0.045 \mu \mathrm{M} \mathrm{BA}+$ $4.5 \mu \mathrm{M}$ 2,4-D; (2) $0.45 \mu \mathrm{M} \mathrm{BA}+4.5 \mu \mathrm{M}$ 2,4-D; (3) $0.045 \mu \mathrm{M}$ KIN + $4.5 \mu \mathrm{M} 2,4-\mathrm{D}$; (4) $0.45 \mu \mathrm{M}$ KIN $+4.5 \mu \mathrm{M}$ 2,4-D. Bars represent standard deviation. Concentration of growth regulators is expressed in $\mu \mathrm{M}$. (B) Plant regenerated from somatic embryo and acclimated under environment conditions. Bar represents $14 \mathrm{~cm}$.

Micropropagation of yacón through organogenesis has previously been reported. From stem cuttings, an average of 7.6 shoots per explant was obtained using $4.4 \mu \mathrm{M}$ BA and $0.49 \mu \mathrm{M}$ IBA (Estrella and Lazart, 1994). Shoot regeneration was also reported through callus induced from leaf segments (Niwa, 2002). Thus, the procedure for somatic embryogenesis allowed a pottentially higher number of regenerated plants, showing the efficiency of micropropagation.

This paper reports an efficient procedure for somatic embryo induction and plant regeneration in yacón. Somatic embryogenesis and plant regeneration were dependent on auxin and cytokinin concentration during the embryo induction phase. Future research shall refine this technique for achieving higher frequencies of embryo proliferation to allow long term culture maintenance.

\section{ACKNOWLEDGEMENTS}

Research support was provided by Fundação de Amparo à Pesquisa do Estado do Rio Grande do Sul/FAPERGS. Authors are grateful to Dr. Júlio
César Bicca-Marques for editing suggestions in the preparation of the manuscript.

\section{RESUMO}

Smallanthus sonchifolius apresenta raízes tuberosas, que contêm grandes quantidades de frutoligosacarídeos e seu uso medicinal tem aumentado devido à propriedade hipoglicemiante relatada para esta espécie. Um sistema eficiente para propagação via embriogênese somática é descrito, utilizando segmentos peciolares cultivados em meio MS suplementado com diversas combinações de BA, cinetina e 2,4-D, sob condições de luz ou escuro. A maioria dos tratamentos resultou na formação de calos embriogênicos; no entanto, a embriogênese somática foi promovida em presença de luz e agregados de embriões somáticos foram observados na superfície dos calos após 50 dias de cultivo. O maior número de embriões foi obtido em presença de $0,45 \mu \mathrm{M}$ BA e 4,5 $\mu \mathrm{M}$ 2,4-D. Os calos embriogênicos foram mantidos em meio MS com adição de $4,5 \mu \mathrm{M}$ BA e $0,045 \mu \mathrm{M}$ 2,4-D. A conversão dos embriões somáticos foi obtida em 
meio MS, com a concentração de sais reduzida à metade, 2 g.L $L^{-1}$ de carvão ativado, sem reguladores de crescimento. As plantas regeneradas foram aclimatadas em condições ambientais, com sobrevivência de $100 \%$.

\section{REFERENCES}

Aybar, M. J.; Riera, A. N.S.; Grau, A. and Sanchez, S.S. (2001), Hypoglycemic effect of the water extract of Smallanthus sonchifolius (yacón) leaves in normal and diabetic rats. J. Ethnopharmacol., 74, 125-132.

Castillo, P.; Márquez, J.; Rubluo, A.; Hernandez, G. and Lara, M. (2000), Plant regeneration from callus and suspension cultures of Valeriana edulis ssp. procera via simultaneous organogenesis and somatic embryogenesis. Plant Sci., 151, 115-119.

Estrella, J. E. and Lazart, J. E. (1994), In vitro propagation of jicama (Polymnia sonchifolius Poepp. and Endlicher): A neglected Andean crop. HortScience, 29, 331.

Grau, A. and Rea, J. (1997), Yacon, Smallanthus sonchifolius (Poepp. and Endl.) H. Robinson. In: Andean roots and tubers: Ahipa, arracacha, maca yacon. Promoting the conservation and use of underutilized and neglected crops, eds. M. Hermann and, J. Heller. Gatersieben/International Plant Genetic Resources Institute. Rome, pp. 199-242. Available at: http://www.cipotato.org/artc/yacon.asp Accessed at Apr, $27^{\text {th }}, 2007$.

Fernando, J.A.; Melo, M.; Soares, M.K.M. and Appezzato-da-Glória, B. (2001), Anatomy of somatic embryogenesis in Carica papaya L. Braz. arch. biol. technol., 44, 247-255.

Fernando, J.A.; Vieira, M.L.C.; Gerardi, I.O. and Appezzato-da-Glória, B. (2002), Anatomical study of somatic embryogenesis in Glycine $\max (\mathrm{L}$.) Merrill. Braz. arch. biol. technol., 45, 277-286.

Fowler, J. and Cohen, L. (1990), Practical statistics for field biology. Open University Press, Buckingham.
George, E.F. (1993), Plant propagation by tissue culture. Part 1. The Technology. 2ed. Exegetics Limited, England.

Gogate, S.S. and Nadgauda, R.S. (2003), Direct induction of somatic embryogenesis from immatue zygotic embryo of cashewnut (Anacardim occidentale L.). Sci. Hort., 97, 75-82.

Martin, K.P. (2003), Plant regeneration through direct somatic embryogenesis on seed coat explants of cashew (Anacardium occidentale L.). Sci. Hort., 98, 299-304.

Martin, A. B.; Cuadrado, Y.; Guerra, H.; Gallego, P.; Hita, O.; Martin, L.; Dorado, A. and Villalobos, N. (2000), Differences in the contents of total sugars, reducing sugars, starch and sucrose in embryogenic and non-embryogenic calli from Medicago arborea L. Plant Sci., 154, 143-151.

Murashige, T. and Skoog, F. (1962), A revised medium for rapid growth and bioassays with tobacco tissue culture. Physiol. Plant., 15, 473-497.

Niwa, M. (2002), Plant regeneration through leaf culture of yacon. J. Japan. Soc. Hort. Sci., 71, 561567.

Rout, G.R.; Samantaray, S. and Das, P. (2000), In vitro somatic embryogenesis from callus cultures of Cephaelis ipecacuanha A. Richard. Sci. Hort., 86, 71-79.

Valentova, K.; Moncion, A.; de Waziers, I. and Ulrichova, J (2005), The effect of Smallanthus sonchifolius leaf extracts on rat hepatic metabolism. Cell Biol. Toxicol., 20, 109-120.

Te-chato, S. and Rungnoi, O. (2000), Induction of somatic embryogenesis from leaves of Sadao Chang (Azadirachta excelsa (Jack) Jacobs). Sci. Hort., 86, 311-321.

Zardini, E. (1991), Ethnobotanical notes on yacón, Polymnia sonchifolia (Asteraceae). Econ. Bot., 45, 72-85. 